\title{
DIMENSI KARAKTER DALAM PENILAIAN PROSES BERKARYA SENI LUKIS PESERTA DIDIK SEKOLAH MENENGAH KEJURUAN
}

\author{
Trie Hartiti Retnowati, Djemari Mardapi, dan Bambang Prihadi \\ Universitas Negeri Yogyakarta \\ E-mail: trihartiti54@gmail.com
}

\begin{abstract}
Abstrak
Penelitian bertujuan menyusun instrumen penilaian nontes berupa penilaian proses berkarya seni lukis yang terintegrasi dengan penilaian karakter, sebagai upaya mempersiapkan peserta didik Sekolah Menengah Kejuruan (SMK) menuju dunia kerja. Teknik penilaian yang digunakan berupa teknik observasi, penilaian diri, dan penilaian antarteman. Berdasarkan studi awal terbatas, pada saat ini belum ada intstrumen penilaian proses berkarya seni lukis yang terintegrasi dengan penilaian karakter untuk menilai proses berkarya seni secara objektif dan utuh. Penelitian ini menggunakan rancangan penelitian dan pengembangan dari Borg and Gall yaitu melakukan (1) studi awal untuk menemukan temuan-temuan penelitian yang terkait dengan produk yang akan dikembangkan, (2) pengembangan instrumen penilaian proses berkarya seni rupa, dan (3) pengujian instrumen di lapangan yang hasilnya digunakan untuk perbaikan. Focus Group Discussion (FGD) digunakan untuk penentuan konstruk, kisi-kisi, dan dilakukan telaah item-item instrumen oleh praktisi dan pakar pendidikan seni rupa. Hasil penelitian ini berupa instrumen penilaian proses berkarya seni lukis yang terdiri atas penilaian persiapan dan penilaian pelaksanaan berkarya seni lukis. Penilaian persiapan berkarya seni lukis berupa lembar observasi dengan rubrik penilaian yang mencakup 6 dimensi, yaitu kesiapan mental, kesiapan fisik, kesiapan alat dan bahan melukis, sikap responsif, dan sikap proaktif dan terdiri atas 8 item dengan empat pilihan. Penilaian pelaksaan berkarya seni lukis berupa lembar penilaian antarteman mencakup 4 dimensi, yaitu penuangan ide, pemanfaatan waktu, dan sikap disiplin dan terdiri atas 9 item dengan dua pilihan. Hasil penelitian menunjukkan bahwa penilaian proses berkarya seni rupa dapat melatih pembentukan karakter pada siswa SMK seni rupa, khususnya untuk program studi seni lukis.
\end{abstract}

Kata kunci: instrumen nontes, berkarya seni rupa, karakter

\section{DIMENSIONS OF CHARACTER IN ASSESSMENT OF PAINTING PROCESS OF VOCATIONAL HIGH SCHOOL STUDENTS}

\begin{abstract}
The objective of this research is to develop a non-test instrument in the form of assessment of painting process which integrates with character assessment as an effort to prepare students of Vocational High School (SMK) in the work field. Assessment techniques used are in the form of techniques of observation, self assessment, and peer assessment. Based on preliminary studies, there is currently no documented assessment of painting process integrated with character judgment to assess the process of artwork objectively and intactly. This research uses research and development design from Borg and Gall which includes (1) preliminary study to find research findings related to product to be developed, (2) development of assessment instrument of fine arts process, and (3) testing instrument in the field where the results are used for improvement. Focus Group Discussion (FGD) is used for the determination of constructions, grids, and the review of instrument items by practitioners and art education experts. The result of this research is the assessment instrument of painting process which consists of the assessment of preparation and the assessment of performance
\end{abstract}


of painting. The assessment of preparation of painting is in the form of observation sheet with rubric assessment covering 6 dimensions, namely mental readiness, physical readiness, preparedness of tools and painting materials, responsive attitude, and proactive attitude and consists of 8 items with four choices. The assessment of performance of painting is in the form of a peer assessment sheet covering 4 dimensions, namely the pouring of ideas, the use of time, and the attitude of discipline and consists of 9 items with two choices. The results showed that the assessment of the process of works of fine arts can train the formation of students characters in vocational high school of fine arts, especially for the study program of painting.

Keywords: non-test instrument, fine arts, character

\section{PENDAHULUAN}

Perkembangan budaya secara global telah menghasilkan berbagai kemajuan dalam kehidupan, tetapi perkembangan tersebut juga dapat membawa dampak negatif yang merugikan bagi generasi ke depan, khususnya berkaitan dengan aspek moral. Oleh karena itu, pendidikan di Indonesia telah berkomitmen untuk meningkatkan pendidikan karakter baik melalui jalur pendidikan formal, informal, maupun nonformal. Pendidikan karakter perlu dilaksanakan secara holistik dan berkesinambungan mulai dari pendidikan anak usia dini hingga pendidikan tinggi.

Pendidikan karakter merupakan investasi nilai kultural untuk membangun watak, moralitas dan kepribadian masyarakat yang dilakukan dalam waktu panjang, kontinyu, intens, konstan, dan konisten. Dengan demikian, pendidikan karakter memberikan kepada peserta didik ilmu, pengetahuan, praktik-praktik budaya perilaku yang berorientasi pada nilai-nilai kehidupan yang ideal, baik yang bersumber dari budaya lokal (kearifan lokal) maupun budaya luar (Tranggono, 2010: 27) .

Komitmen nasional tentang perlunya pendidikan karakter secara imperatif tertuang dalam Pasal 3 Undang-undang Nomor 20 Tahun 2003 tentang Sistem Pendidikan Nasional. Dalam Undang-undang tersebut dinyatakan bahwa "Pendidikan nasional berfungsi mengembangkan kemampuan dan membentuk watak serta peradaban bangsa yang bermartabat dalam rangka mencerdaskan kehidupan bangsa, bertujuan untuk berkembangnya potensi peserta didik agar menjadi manusia yang beriman dan bertakwa kepada Tuhan Yang Maha Esa, berakhlak mulia, sehat, berilmu, cakap, kreatif, mandiri, dan menjadi warga negara yang demokratis serta bertanggung jawab." Tujuan pendidikan nasional tersebut menunjukkan bahwa sebagian besar potensi peserta didik yang ingin dikembangkan berhubungan erat dengan pendidikan karakter. Dengan demikian, pendidikan di Indonesia tidak hanya dilaksanakan untuk mengembangkan pengetahuan dan ketrampilan, tetapi juga karakter peserta didik.

Dalam implementasinya, programpendidikan karakter pada prinsipnya tidak dilaksanakan dalam bentuk mata pelajaran tersendiri di dalam kurikulum, tetapi terintegrasi dengan mata pelajaran yang lain serta program yang lain seperti pengembangan diri dan budaya sekolah. Dengan demikian, setiap program pelajaran bertanggung jawab terhadap pengembangan karakter sesuai dengan karakteristiknya masingmasing.

Terkait dengan pendidikan karakter, pendidikan seni di sekolah secara umum memiliki peranan penting karena selain sebagai pendidikan estetika seni juga berkenaan dengan nilainilai sosial dan budaya. Mata pelajaran Seni Budaya memiliki keunikan, kebermaknaan, dan kebermanfaatan bagi kebutuhan perkembangan peserta didik yang diberikan melalui pengalaman estetik dalam bentuk kegiatan berekspresi/ berkreasi dan berapresiasi seni. Mata pelajaran ini diberikan di semua jenjang sekolah dasar dan menengah, termasuk Sekolah Menengah Kejuruan (SMK).

Kurikulum pendidikan kejuruan mengarah kepada multiskills dengan basic skills yang kuat, 
memberikan penekanan kepada intelectual skills, kemampuan beradaptasi dan self-training, serta ramah dengan lingkungan setempat (Samani, 1995; Akhir, 1997). Dalam basic skills, tercakup life skills, antara lain keimanan dan moralitas, kemampuan kerja sama, kemampuan menggali dan mengolah informasi untuk menghadapi situasi yang dihadapi, kemampuan memecahkan masalah, serta kemampuan berkomunikasi. Kemampuan tersebut berada dalam ranah afektif yang tercakup di dalamnya karakter yang diperlukan oleh peserta didik di mana pun dia bekerja dan bermasyarakat.

Sesuai dengan standar penilaian yang telah ditetapkan oleh Kemendikbud, setiap pembelajaran baik di kelas maupun di luar kelas menuntut dilaksanakannya penilaian oleh pemerintah, sekolah, maupun pendidik. Penilaian oleh pendidik (guru) khususnya memiliki peranan penting karena tidak hanya berfungsi mengukur hasil belajar peserta didik (assessment of learning), tetapi juga mendorong atau mendukung proses pembelajaran (assesment for learning dan assessment as learning). Penilaian oleh pendidik meliputi dimensi pengetahuan, keterampilan, maupun sikap yang dilakukan dengan berbagai teknik dan bentuk instrumen. Terkait dengan pendidikan karakter, penilaian proses memiliki peranan yang sangat penting.

Karakteristik SMK adalah menyiapkan lulusan sesuai dengan tuntutan dunia kerja. Untuk memperkuat kemampuan profesional peserta didik, SMK melakukan program Praktik Kerja Industri (Prakerin) melalui kerja sama dengan pihak Dunia Usaha dan Industri (DUDI). SMK di bidang seni rupa khususnya bekerja sama dengan DUDI sesuai bidangnya, termasuk dengan kalangan seniman. Dengan berinteraksi secara langsung dengan seniman atau pengrajin dan dunia kerjanya, peserta didik program studi Seni Lukis diharapkan dapat mengembangkan kemampuannya secara utuh, meliputi pengetahuan, keterampilan, dan sikap atau karakter sesuai dengan kebutuhan masyarakat.

Salah satu kendala yang dihadapi oleh pendidik dalam melaksanakan penilaian adalah belum tersedianya contoh instrumen penilaian afektif yang memadai untuk menilai aspek proses yang di tercakup di dalamnya aspek karakter. Oleh karena itu, melalui penelitian ini dikembangkan instrumen penilaian proses pembelajaran seni lukis yang teringrasi di dalamnya dimensi karakter. Rumusan masalah penelitian ini adalah bagaimana mengembangkan instrumen penilaian proses Prakerin seni lukis yang terintegrasi di dalamnya dimensi karakter untuk peserta didik Sekolah Menengah Kejuruan (SMK) seni rupa? Penelitian ini bertujuan menyusun instrumen penilaian proses Pakerin seni lukis yang terintegrasi di dalamnya dimensi karakter untuk peserta didik SMK seni rupa.

\section{METODE}

Penelitian ini merupakan penelitian dan pengembangan (research and development). Penelitian jenis R\&D memiliki empat ciri pokok sebagai berikut, yaitu melakukan (1) studi awal untuk menemukan temuan-temuan penelitian yang terkait dengan produk yang akan dikembangkan, (2) pengembangan produk berdasarkan temuan- temuan penelitian tersebut, (3) pengujian lapangan dalam situasi nyata di mana produk tersebut akan digunakan, dan (4) perbaikan produk berdasarkan kelemahankelemahan yang ditemukan dalam pengujian lapangan (Borg and Gall, 1983).

Secara rinci, penelitian ini dilaksanakan dengan tahap-tahap seperti tersaji pada Gambar 1. Pertama, studi awal dilakukan di lapangan untuk menemukan bahwa instruktur belum menggunakan instrumen proses yang tercakup di dalamnya aspek karakter bagi peserta didik yang melaksanakan Prakerin di bidang seni lukis. Selain itu, dilakukan kajian literatur dan hasil-hasil penelitian sebelumnya sebagai landasaran untuk mengembangkan produk yakni instrumen penilaian proses yang mencakup dimensi karakter. Kedua, dikembangkan prototipe instrumen berupa kisi-kisi yang meliputi dimensi, deskripsi, dan indikator serta lembar observasi dan lembar penilaian antarteman dengan item-item yang ditentukan berdasarkan indikator. Ketiga, dilakukan validasi instrumen tersebut oleh pakar yakni 
dosen-dosen di Jurusan Pendidikan Seni Rupa Fakultas Bahasa dan Seni Universitas Negeri Yogyakarta. Berikut sajian visualnya.

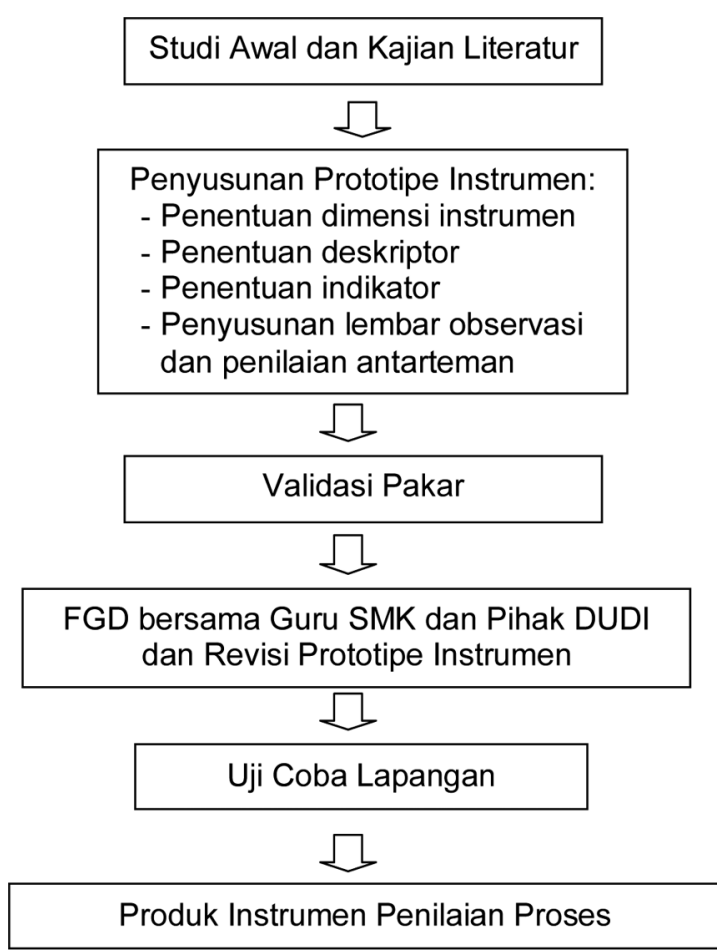

Gambar 1.

Skema Alur Pengembangan Instrumen

Penilaian Proses Berkarya Seni Lukis

Keempat, dilakukan validasi lebih lanjut dengan Focus Group Disscussion (FGD) bersama guru SMK seni rupa di Yogyakarta SMK, pengelola dunia usaha/sanggar, dan pakar seni lukis setempat dan berdasarkan hasil FGD tersebut selanjutnya dilakukan perbaikan prototipe instrumen. Kelima, selanjutnya dilakukan ujicoba lapangan untuk mengetahui kualitas produk instrumen yang dihasilkan.

\section{HASIL DAN PEMBAHASAN}

Produk instrumen penilaian proses berkarya seni lukis yang dihasilkan meliputi kisi-kisi dan lembar penilaian untuk persiapan dan pelaksanaan berkarya seni lukis. Lembar penilaian persiapan Prakerin berupa lembar observasi yang diisi oleh pihak DUDI dan lembar penilaian pelaksanaan Prakerin berupa lembar penilaian antarteman.
Kisi-kisi instrumen penilaian persiapan berkarya seni lukis yang dikembangkan meliputi 6 dimensi yaitu kesiapan mental, kesiapan fisik, kesiapan alat dan bahan melukis, sikap responsif, dan sikap proaktif. Pada Tabel 1 disajikan kisikisi isntrumen tersebut yang meliputi dimensi, deskripsi, dan indikator. Berdasarkan kisi-kisi tersebut dikembangkan lembar observasi yang disajikan pada Gambar 2. Untuk memberikan pedoman bagi penilai (pihak DUDI) dalam memberikan penilaian terhadap peserta didik, disusun rubrik penilaian yang disajikan pada Tabel 2.

Hasil penilaian persiapan prakerin seni lukis berdasarkan lembar observasi tersebut selanjutnya diolah dengan rumus sebagai berikut.

Nilai $=\frac{\text { Jumlah skor yang diperoleh }}{\text { Jumlah skor maksimum }} \times 100$

Kisi-kisi instrumen penilaian pelaksanaan persiapan Prakerin yang dikembangkan meliputi 6 dimensi yaitu memusatkan perhatian, memiliki kepercayaan diri, memiliki badan sehat, memiliki semangat, serta kesiapan alat dan bahan melukis. Pada Tabel 1 disajikan kisi-kisi isntrumen penilaian persiapan Prakerin yang meliputi dimensi, deskripsi, dan indikator. Berdasarkan kisi-kisi tersebut dikembangkan lembar observasi yang disajikan pada Gambar 2. Untuk memberikan pedoman bagi penilai (pihak DUDI) dalam memberikan penilaian terhadap peserta didik, disusun rubrik penilaian yang disajikan pada Tabel 2.

Instrumen penilaian proses yang kedua adalah penilaian pelaksanaan berkarya seni lukis yang mencakup empat dimensi yaitu pengembangan ide, penuangan ide melalui media, pemanfaatan waktu, dan sikap disiplin. Tabel 3 menunjukkan kisi-kisi penilaian pelaksanaan Prakerin yang meliputi keempat dimensi tersebut serta deskripsi dan indikatornya. Penilaian pelaksaan berkarya seni lukis ini dilakukan dengan lembar penilaian antarteman seperti pada Gambar 3.

Hasil penilaian antarteman dengan lembar penilaian tersebut selanjutnya dinilai dengan formula sebagai berikut. 
Tabel 1. Kisi-Kisi Instrumen Penilaian Persiapan Prakerin Seni Lukis

\begin{tabular}{|c|c|c|c|}
\hline No. & Dimensi & Deskriptor & Indikator \\
\hline 1 & $\begin{array}{l}\text { Kesiapan peserta } \\
\text { didik secara mental }\end{array}$ & $\begin{array}{l}\text { Peserta didik memiliki } \\
\text { persepsi dan sikap positif } \\
\text { untuk melaksanakan Prakerin }\end{array}$ & $\begin{array}{l}\text { Memusatkan perhatian dan memiliki } \\
\text { kepercayaan diri untuk melaksanakan } \\
\text { Prakerin }\end{array}$ \\
\hline 2 & $\begin{array}{l}\text { Kesiapan peserta } \\
\text { didik secara fisik }\end{array}$ & $\begin{array}{l}\text { Kesehatan fisik peserta didik } \\
\text { untuk melaksanakan Prakerin }\end{array}$ & $\begin{array}{l}\text { Memiliki fisik yang sehat dan } \\
\text { bersemangat untuk melaksanakan } \\
\text { Prakerin }\end{array}$ \\
\hline 3 & $\begin{array}{l}\text { Kesiapan alat dan } \\
\text { bahan melukis }\end{array}$ & $\begin{array}{l}\text { Kesiapan peserta didik engan } \\
\text { alat dan bahan melukis untuk } \\
\text { Prakerin }\end{array}$ & $\begin{array}{l}\text { Tersedia kanvas, cat minyak, kuas, } \\
\text { palet, easel (standar), minyak cat, } \\
\text { terpentin, pastel, cat air, cat poster, cat } \\
\text { acrilik, kain lap, dan pigura }\end{array}$ \\
\hline 4 & $\begin{array}{l}\text { Kesiapan } \\
\text { kelengkapan } \\
\text { keselamatan kerja }\end{array}$ & $\begin{array}{l}\text { Kesiapan peserta didik dengan } \\
\text { kelengkapan keselamatan } \\
\text { kerja untuk melukis }\end{array}$ & $\begin{array}{l}\text { Menyediakan pakaian dan } \\
\text { kelengkapan seperti lap, masker, dan } \\
\text { sarung tangan untuk melukis }\end{array}$ \\
\hline 5 & Sikap responsif & $\begin{array}{l}\text { Sikap responsif untuk } \\
\text { melaksanakan Prakerin }\end{array}$ & $\begin{array}{l}\text { Bertindak dengan cepat mengikuti } \\
\text { perintah/arahan pihak pembimbing } \\
\text { dan DU/DI }\end{array}$ \\
\hline 6 & Sikap proaktif & $\begin{array}{l}\text { Sikap proaktif untuk } \\
\text { melaksanakan Prakerin }\end{array}$ & $\begin{array}{l}\text { Meminta arahan/petunjuk pihak } \\
\text { pembimbing dan DU/DI }\end{array}$ \\
\hline
\end{tabular}

\section{LEMBAR OBSERVASI}

Nama siswa

Asal Sekolah

SMK

Nama Pembimbing :

Nama DU/DI

Alamat DU/DI

Berdasarkan observasi yang Saudara lakukan, berikan penilaian terhadap kinerja siswa dalam kegiatan awal Prakerin Seni Lukis dengan memberikan tanda centang $(\sqrt{ })$ pada rentang skor sesuai dengan rubrik penilaian!

\begin{tabular}{|c|l|c|c|c|c|c|}
\hline \multirow{2}{*}{ No. } & \multirow{2}{*}{ Dimensi } & \multicolumn{4}{c|}{ Rentang Skor } & \multirow{2}{*}{ Skor } \\
\cline { 3 - 5 } & & 1 & 2 & 3 & 4 & \\
\hline 1 & Memusatkan perhatian & & & & & \\
\hline 2 & Memiliki kepercayaan diri & & & & & \\
\hline 3 & Memiliki badan yang sehat & & & & & \\
\hline 4 & Memiiki semangat & & & & & \\
\hline 5 & Kesiapan alat dan bahan melukis & & & & \\
\hline 6 & Kesiapan kelengkapan keselamatan kerja & & & & & \\
\hline 7 & Sikap responsive & & & & & \\
\hline 8 & Sikap proaktif & & & & Jumlah & \\
\hline \multicolumn{2}{|l|}{} \\
\hline
\end{tabular}

Gambar 2. Lembar Observasi Kegiatan Awal Prakerin Seni Lukis

Nilai $=\frac{\text { Jumlah skor yang diperoleh }}{\text { Jumlah skor maksimum }} \times 100$

Hasil ujicoba lapangan menunjukkan bahwa instrumen penilaian proses berkarya seni lukis yang dikembangkan mampu mengukur kinerja siswa dalam ranah afektif yang di dalamnya terintegrasi dimensi karakter. Instrumen penilaian tersebut dapat berguna untuk assessment for learning dan assessment as learning karena 
Tabel 2. Rubrik Penilaian Kegiatan Awal Prakerin Seni Lukis

\begin{tabular}{|c|c|c|c|c|c|}
\hline \multirow{2}{*}{ No. } & \multirow{2}{*}{ Dimensi } & \multicolumn{4}{|c|}{ Rentang Skor } \\
\hline & & 1 & 2 & 3 & 4 \\
\hline 1 & $\begin{array}{l}\text { Memusatkan } \\
\text { perhatian }\end{array}$ & $\begin{array}{l}\text { Peserta didik } \\
\text { jarang memusatkan } \\
\text { perhatian untuk } \\
\text { melaksanakan } \\
\text { Prakerin. }\end{array}$ & $\begin{array}{l}\text { Peserta didik } \\
\text { kadang-kadang } \\
\text { memusatkan } \\
\text { perhatian untuk } \\
\text { melaksanakan } \\
\text { Prakerin. }\end{array}$ & $\begin{array}{l}\text { Peserta didik } \\
\text { sering memusatkan } \\
\text { perhatian untuk } \\
\text { melaksanakan } \\
\text { Prakerin. }\end{array}$ & $\begin{array}{l}\text { Peserta didik } \\
\text { selalu memusatkan } \\
\text { perhatian untuk } \\
\text { melaksanakan } \\
\text { Prakerin. }\end{array}$ \\
\hline 2 & $\begin{array}{l}\text { Memiliki } \\
\text { kepercayaan } \\
\text { diri }\end{array}$ & $\begin{array}{l}\text { Peserta didik } \\
\text { tidak memiliki } \\
\text { kepercayaan diri } \\
\text { untuk melaksanakan } \\
\text { Prakerin. }\end{array}$ & $\begin{array}{l}\text { Peserta didik } \\
\text { kurang memiliki } \\
\text { kepercayaan diri } \\
\text { untuk melaksanakan } \\
\text { Prakerin. }\end{array}$ & $\begin{array}{l}\text { Peserta didik } \\
\text { cukup memiliki } \\
\text { kepercayaan diri } \\
\text { untuk melaksanakan } \\
\text { Prakerin. }\end{array}$ & $\begin{array}{l}\text { Peserta didik } \\
\text { memiliki } \\
\text { kepercayaan } \\
\text { diri untuk } \\
\text { melaksanakan } \\
\text { Prakerin. }\end{array}$ \\
\hline 3 & $\begin{array}{l}\text { Memiliki } \\
\text { konisi badan } \\
\text { yang sehat }\end{array}$ & $\begin{array}{l}\text { Peserta didik dalam } \\
\text { keadaan tidak sehat, } \\
\text { lemah secara fisik, } \\
\text { untuk melaksanakan } \\
\text { Prakerin. }\end{array}$ & $\begin{array}{l}\text { Peserta didik dalam } \\
\text { keadaan kurang } \\
\text { sehat, agak lemah } \\
\text { secara fisik, untuk } \\
\text { melaksanakan } \\
\text { Prakerin. }\end{array}$ & $\begin{array}{l}\text { Peserta didik dalam } \\
\text { keadaan cukup } \\
\text { sehat, cukup kuat } \\
\text { secara fisik untuk } \\
\text { melaksanakan } \\
\text { Prakerin. }\end{array}$ & $\begin{array}{l}\text { Peserta didik dalam } \\
\text { keadaan sehat, kuat } \\
\text { secara fisik, untuk } \\
\text { melaksanakan } \\
\text { Prakerin. }\end{array}$ \\
\hline 4 & $\begin{array}{l}\text { Memiliki } \\
\text { semangat }\end{array}$ & $\begin{array}{l}\text { Peserta didik jarang } \\
\text { bersemangat untuk } \\
\text { melaksanakan } \\
\text { Prakerin. }\end{array}$ & $\begin{array}{l}\text { Peserta didik } \\
\text { kadang-kadang } \\
\text { bersemangat untuk } \\
\text { melaksanakan } \\
\text { Prakerin. }\end{array}$ & $\begin{array}{l}\text { Peserta didik sering } \\
\text { bersemangat untuk } \\
\text { melaksanakan } \\
\text { Prakerin. }\end{array}$ & $\begin{array}{l}\text { Peserta didik selalu } \\
\text { bersemangat untuk } \\
\text { melaksanakan } \\
\text { Prakerin. }\end{array}$ \\
\hline 5 & $\begin{array}{l}\text { Kesiapan alat } \\
\text { dan bahan } \\
\text { melukis }\end{array}$ & $\begin{array}{l}\text { Peserta didik } \\
\text { menyiapkan } \\
\text { sebagian kecil alat } \\
\text { dan bahan melukis } \\
\text { untuk prakerin } \\
\text { (kanvas, cat minyak, } \\
\text { kuas, pallet, } \\
\text { essel, minyak cat, } \\
\text { terpentin, pastel, cat } \\
\text { air, cat poster, cat } \\
\text { acrilyc, kain lap, } \\
\text { dan pigura). }\end{array}$ & $\begin{array}{l}\text { Peserta didik } \\
\text { menyiapkan } \\
\text { sebagian alat dan } \\
\text { bahan melukis } \\
\text { untuk prakerin } \\
\text { (kanvas, cat minyak, } \\
\text { kuas, pallet, } \\
\text { essel, minyak cat, } \\
\text { terpentin, pastel, cat } \\
\text { air, cat poster, cat } \\
\text { acrilyc, kain lap, } \\
\text { dan pigura). }\end{array}$ & $\begin{array}{l}\text { Peserta didik } \\
\text { menyiapkan } \\
\text { sebagian besar alat } \\
\text { dan bahan melukis } \\
\text { untuk prakerin } \\
\text { (kanvas, cat minyak, } \\
\text { kuas, pallet, } \\
\text { essel, minyak cat, } \\
\text { terpentin, pastel, cat } \\
\text { air, cat poster, cat } \\
\text { acrilyc, kain lap, } \\
\text { dan pigura). }\end{array}$ & $\begin{array}{l}\text { Peserta didik } \\
\text { menyiapkan } \\
\text { seluruh alat dan } \\
\text { bahan melukis } \\
\text { untuk prakerin } \\
\text { (kanvas, cat } \\
\text { minyak, kuas, } \\
\text { pallet, essel, } \\
\text { minyak cat, } \\
\text { terpentin, pastel, } \\
\text { cat air, cat poster, } \\
\text { cat acrilyc, kain } \\
\text { lap, dan pigura). }\end{array}$ \\
\hline 6 & $\begin{array}{l}\text { Kesiapan } \\
\text { kelengkapan } \\
\text { keselamatan } \\
\text { kerja }\end{array}$ & $\begin{array}{l}\text { Peserta didik } \\
\text { jarang menyiapkan } \\
\text { pakaian kerja dan } \\
\text { perlengkapan } \\
\text { (lap, masker, dan } \\
\text { sarung tangan untuk } \\
\text { melukis) dengan } \\
\text { lengkap. }\end{array}$ & $\begin{array}{l}\text { Peserta didik } \\
\text { kadang-kadang } \\
\text { menyiapkan } \\
\text { pakaian kerja dan } \\
\text { perlengkapan } \\
\text { (lap, masker, dan } \\
\text { sarung tangan untuk } \\
\text { melukis) dengan } \\
\text { lengkap. }\end{array}$ & $\begin{array}{l}\text { Peserta didik } \\
\text { sering menyiapkan } \\
\text { pakaian kerja dan } \\
\text { perlengkapan } \\
\text { (lap, masker, dan } \\
\text { sarung tangan untuk } \\
\text { melukis) dengan } \\
\text { lengkap. }\end{array}$ & $\begin{array}{l}\text { Peserta didik } \\
\text { selalu menyiapkan } \\
\text { pakaian kerja dan } \\
\text { perlengkapan (lap, } \\
\text { masker, dan sarung } \\
\text { tangan untuk } \\
\text { melukis) dengan } \\
\text { lengkap. }\end{array}$ \\
\hline 7 & $\begin{array}{l}\text { Sikap } \\
\text { responsif }\end{array}$ & $\begin{array}{l}\text { Peserta didik jarang } \\
\text { melakukan tindakan } \\
\text { secara cepat } \\
\text { terhadap perintah/ } \\
\text { arahan pembimbing } \\
\text { dan dudi. }\end{array}$ & $\begin{array}{l}\text { Peserta didik } \\
\text { kadang-kadang } \\
\text { melakukan tindakan } \\
\text { secara cepat } \\
\text { terhadap perintah/ } \\
\text { arahan pembimbing } \\
\text { dan dudi. }\end{array}$ & $\begin{array}{l}\text { Peserta didik sering } \\
\text { melakukan tindakan } \\
\text { secara cepat } \\
\text { terhadap perintah/ } \\
\text { arahan pembimbing } \\
\text { dan dudi. }\end{array}$ & $\begin{array}{l}\text { Peserta didik } \\
\text { selalu melakukan } \\
\text { tindakan secara } \\
\text { cepat terhadap } \\
\text { perintah/arahan } \\
\text { pembimbing dan } \\
\text { dudi. }\end{array}$ \\
\hline 8 & Sikap proaktif & $\begin{array}{l}\text { Peserta didik jarang } \\
\text { meminta arahan/ } \\
\text { petunjuk pihak } \\
\text { pembimbing dan } \\
\text { DU/DI. }\end{array}$ & $\begin{array}{l}\text { Peserta didik } \\
\text { kadang-kadang } \\
\text { meminta arahan/ } \\
\text { petunjuk pihak } \\
\text { pembimbing dan } \\
\text { DU/DI. }\end{array}$ & $\begin{array}{l}\text { Peserta didik sering } \\
\text { meminta arahan/ } \\
\text { petunjuk pihak } \\
\text { pembimbing dan } \\
\text { DU/DI. }\end{array}$ & $\begin{array}{l}\text { Peserta didik selalu } \\
\text { meminta arahan/ } \\
\text { petunjuk pihak } \\
\text { pembimbing dan } \\
\text { DU/DI. }\end{array}$ \\
\hline
\end{tabular}


Tabel 3. Instrumen Penilaian Proses Prakerin Seni Lukis

\begin{tabular}{llll}
\hline No. & \multicolumn{1}{c}{ Dimensi } & \multicolumn{1}{c}{ Deskripsi } & \multicolumn{1}{c}{ Indikator } \\
\hline 1. & Pengembangan ide & $\begin{array}{l}\text { Siswa mengembangkan ide dengan } \\
\text { cepat dan kreatif. }\end{array}$ & $\begin{array}{l}\text { Siswa melakukan eksplorasi } \\
\text { tema dan bentuk dengan cepat } \\
\text { dan kreatif. }\end{array}$ \\
2 & $\begin{array}{l}\text { Penuangan ide } \\
\text { melalui media }\end{array}$ & $\begin{array}{l}\text { Siswa menggunakan bahan dan alat } \\
\text { secara efektif. }\end{array}$ & $\begin{array}{l}\text { Siswa menggunakan bahan dan } \\
\text { alat sesuai dengan prosedur dan } \\
\text { ekspresinya dengan lancar. }\end{array}$ \\
& Pemanfatan waktu & $\begin{array}{l}\text { Siswa menggunakan waktu secara } \\
\text { efisien. }\end{array}$ & $\begin{array}{l}\text { Siswa menggunakan langkah } \\
\text { yang efektif dalam mengerjakan } \\
\text { karya lukisan } \\
\text { Siswa mengerjakan tugas } \\
\text { Prakerin sesuai dengan arahan } \\
\text { pembimbing dan jadwal yang } \\
\text { telah ditentukan. }\end{array}$ \\
\hline
\end{tabular}

\section{LEMBAR PENILAIAN ANTARTEMAN \\ PROSES MELAKSANAKAN PRAKERIN SENI LUKIS}

Nama Siswa

No. Induk

Asal Sekolah

SMK

Nama DU/DI

Alamat DU/DI

Berikan penilaian terhadap kinerja teman Anda dalam melaksanakan Prakerin Seni Lukis dengan memberi tanda centang $(\sqrt{ })$ pada kolom jawaban "Ya" atau "Tidak" sesuai dengan pendapat Anda!

\begin{tabular}{|c|c|c|c|}
\hline Pernyataan & \multirow{2}{*}{ Ya } & \multirow{2}{*}{ Tidak } & \multirow{2}{*}{ Skor } \\
\hline Sesuai dengan pengamatan saya, siswa tersebut telah: & & & \\
\hline 1. melakukan eksplorasi tema dengan kreatif. & & & \\
\hline 2. melakukan eksplorasi bentuk (komposisi) dengan kreatif. & & & \\
\hline 3. menggunakan bahan dan alat sesuai prosedur dengan lancar. & & & \\
\hline 4. menggunakan bahan dan alat sesuai ekspresi dengan lancar. & & & \\
\hline 5. mengerjakan karya lukisan dengan tekun & & & \\
\hline 6. menggunakan bahan secara efisien & & & \\
\hline 7. menggunakan langkah yang efektif dalam mengerjakan karya lukisan. & & & \\
\hline 8. mengerjakan tugas Prakerin sesuai dengan arahan pembimbing. & & & \\
\hline 9. mengerjakan tugas Prakerin sesuai dengan jadwal yang telah ditentukan. & & & \\
\hline & & Jumlah & \\
\hline
\end{tabular}

Penilai :
Nama Siswa
No. Induk
Tanda Tangan

Gambar 4. Instrumen Penilaian Antarteman Proses Melaksanakan Prakerin Seni Lukis

merupakan penilaian formatif dan melibatkan peserta didik dalam proses pembelajaran.

Dengan instrumen yang dikembangkan tersebut dapat diketahui bahwa pada umumnya peserta Prakerin kurang menunjukkan sikap proaktif selama kegiatan awal Prakerin. Peserta Prakerin masih menunggu instruksi dari pembimbing Prakerin untuk melakukan 
apa yang harus mereka lakukan. Selain itu, peserta Prakerin peserta kurang maksimal dalam melakukan eksplorasi bentuk (komposisi) dengan cepat dan dalam menggunakan bahan dan alat sesuai ekspresi dengan lancar pada saat proses Prakerin. Dengan kurang maksimalnya kinerja peserta didik pada dua aspek tersebut menjadikan hasil penilaian proses Prakerin mereka tidak maksimal.. Untuk itu pembimbing Prakerin harus mampu menemukan solusi dari permasalahan tersebut untuk meningkatkan hasil penilaian proses Prakerin.

Hasil penelitian menunjukkan bahwa reliabilitas instrumen Pedoman penilaian Prakerin seni lukis terintegrasi dengan karakter untuk peserta didik Sekolah Menengah Kejuruan masih rendah. Hal ini dikarenakan subjek uji coba kecil (10 orang). Dengan demikian perlu mendapat perhatian karena menurut Edward $\mathrm{H}$. Haertel. (2006: 67) bahwa koefisien reliabilitas diharapkan minimal 0,70 .

\section{KESIMPULAN}

Melalui penelitian ini tersusun instrumen penilaian proses berkarya seni lukis untuk menilai kinerja peserta didik sekolah menengah kejuruan (SMK) seni rupa yang terintegrasi di dalamnya dimensi karakter. Instrumen penilaian tersebut terdiri atas instrumen penilaian persiapan dan instrumen penilaian pelaksanaan berkarya seni lukis. Penilaian persiapan berkarya seni lukis berupa lembar observasi dengan rubrik penilaian yang mencakup 6 dimensi, yaitu kesiapan mental, kesiapan fisik, kesiapan alat dan bahan melukis, sikap responsif, dan sikap proaktif dan terdiri atas 8 item dengan empat pilihan. Penilaian pelaksaan berkarya seni lukis berupa lembar penilaian antarteman mencakup 4 dimensi, yaitu penuangan ide, pemanfaatan waktu, dan sikap disiplin dan terdiri atas 9 item dengan dua pilihan. Hasil penelitian menunjukkan bahwa penilaian proses berkarya seni rupa berguna untuk melatih pembentukan karakter pada siswa SMK seni rupa, khususnya untuk program studi seni lukis.

\section{DAFTAR PUSTAKA}

Borg, W.R. and Gall, M.D. (1983). Educational Research: An Introduction. London: Longman, Inc.

Haertel, Edward H.. (2006). Educational Measurerment. Edited Robert L. Brenan: American Council on Education and Praeger Publlishers.

Samani, Muchlas dan Hariyanto (2011). Konsep dan Model Pendidikan Karakter, Bandung: PT Remaja Rosda Karya.

Tranggono, Indra. (26 April 2010), Pendidikan Karakter. Kedaulatan Rakyat .

Undang-undang Nomor 20 Tahun 2003 tentang Sistem Pendidikan Nasional. 